\title{
DIFFERENTIATION OF RESPONSIBILITY AS AN EXPRESSION OF THE PRINCIPLE OF JUSTICE
}

\author{
Alexandra Yu. Bokovnya ${ }^{1}$ \\ Fedor R. Sundurov ${ }^{2}$
}

\begin{abstract}
The proposed article studies the differentiation of criminal responsibility from the standpoint of implementing the principle of justice. The authors point out, along with positive decisions of the legislator, to the imperfection of the regulation in the Criminal Code of the Russian Federation of differentiation of criminal responsibility from the standpoint of the principle of justice.
\end{abstract}

Keywords: criminal law; criminal liability; differentiation.

\section{Introduction}

Differentiation of criminal responsibility is one of the main directions of development of modern criminal law policy of Russia, as well as of many other states. This is a kind of key to the fairness of the norms of criminal law and its practice. The literature often focuses on the appropriateness and fairness of imprisonment [Cornel, 2010], while it is noted that in some states, when differentiating punishment, the role of imprisonment is overestimated (for example, in the US), and in others (FRG) it is largely limited [Albrecht, 2015], and sometimes differentiation is reduced to the individualization of punishment [Berar, 2014].

Despite some differences of opinion in both Russian and foreign literature, the fundamental importance of differentiating criminal responsibility (punishment) for the implementation of the principle of justice is emphasized. In terms of further improvement of the criminal law, it seems necessary to disclose the influence mechanism of the

\footnotetext{
${ }^{1}$ Kazan Federal University, Faculty of Law, Criminal law Department, Kazan, Russia, e-mail: at240886@gmail.com, phone 8(843)2337103

${ }^{2}$ Kazan Federal University, Faculty of Law, Criminal law Department, Kazan, Russia, e-mail: kafedra.ksu@yandex.ru, phone 8(843)2337103
} 


\section{Sireite}

Periódico do Núcleo de Estudos e Pesquisas sobre Gênero e Direito

Centro de Ciências Jurídicas - Universidade Federal da Paraíba

V. 8 - No 07 - Ano 2019 - Special Edition

ISSN | 2179-7137 | http://periodicos.ufpb.br/ojs2/index.php/ged/index

differentiation of responsibility on the election of fair measures of a criminal law nature, which have often a high punitive potential.

In the context of the stated problem, attention should also be paid to the systematization of criteria for differentiation and justice of punishment and other criminal legal measures.

\section{Materials and methods}

The work is based on the provisions of Articles 2, 5, 6, 43 regulating the tasks of the Criminal Code, principles of equality and fairness, purpose of punishment, Article 15 of the Criminal Code of the Russian Federation, establishing the categories of crimes, Articles $104^{1}, 104^{2}, 104^{3}$ of the Criminal Code of the Russian Federation, regulating confiscation of property, Article 44 of the Criminal Code of the Republic of Belarus, Article 16 of the Criminal Code of the Republic of Uzbekistan, Article 137 of the Criminal Procedure Code of France, clauses 64 and 66 of the Criminal Code of Germany.
The reliability of results obtained is ensured on the basis of the analysis of significant and necessary array of legislative norms, statistical data on the application of criminal law norms, as well as use of various research methods of legal establishments: logical, historical-legal, comparative jurisprudence, systemstructural, etc.

\section{Results and discussion}

Differentiation of criminal responsibility as a result of the activity of legislative body is a system of differentials, that is, differences in its content, limits, grounds and forms of implementation stipulated in the criminal law based on socially significant, typical properties of a crime and the perpetrator's identity.

Since the criminal law stipulates responsibility for the various, in their nature, dangers, degree of guilt, motives and objectives of the crime, its differentiation seems inevitable. On the basis of consolidating the system of differentials of criminal responsibility, the legislator determines priorities in the 


\section{Direite}

Periódico do Núcleo de Estudos e Pesquisas sobre Gênero e Direito

Centro de Ciências Jurídicas - Universidade Federal da Paraíba

V. 8 - No 07 - Ano 2019 - Special Edition

ISSN | 2179-7137 | http://periodicos.ufpb.br/ojs2/index.php/ged/index

criminal law, and subsequently the criminal-executive policy of the state, it is intended to streamline the law enforcement practice and ensure its uniformity.

Differentiation of criminal responsibility is mainly aimed at the implementation of the principles of justice and equality of citizens before the law. It is known that the fairness of a punishment imposed by a court or another measure of a criminal law nature is predetermined primarily by the validity of sanctions stipulated in the Criminal Code of the Russian Federation. Already in the establishment of penal sanctions, the legislator determines the possible limits of justice depending mainly on the nature of crime committed (let us say, a sentence of imprisonment for a term of 6 to 15 years for murder without qualifying signs (Part 1 of Article 105 of the Criminal Code of the Russian Federation) and this type of punishment for up to 2 years for deliberately false denunciation (Part 1 of Article 306 of the Criminal Code of the Russian Federation), as well as on the typical degree of its public danger (for example, Part 3 of Article 106 of the Criminal Code of the Russian Federation stipulates an imprisonment up to 4 years for causing death by negligence to two or more persons, but Part 2 of Article 105 of the Criminal Code of the Russian Federation stipulates the same punishment for the murder of two or more persons) , an imprisonment for a period of 8 to 20 years, or life imprisonment, or death penalty. As can be seen, such a typical feature as a form of guilt significantly affects the degree of public danger of a crime and, accordingly, the regulation of criminal responsibility limits in the law.

The nature and degree of public danger of a crime only predetermine the limits of criminal responsibility and its fairness, since the punishment chosen by the court or some other measure of criminal law nature shall correspond, moreover, to the circumstances of its commission and the perpetrator's identity. Such criminal law measures that, although formally appointed within the sanction limits, ignore these circumstances and the perpetrator's identity, cannot be recognized as fair Therefore, the 
Sateinere

Periódico do Núcleo de Estudos e Pesquisas sobre Gênero e Direito

Centro de Ciências Jurídicas - Universidade Federal da Paraíba

V. 8 - No 07 - Ano 2019 - Special Edition

ISSN | 2179-7137 | http://periodicos.ufpb.br/ojs2/index.php/ged/index

requirement of justice is not fully implemented by the legislative regulation of the differentiation of criminal responsibility, since it involves taking into account both the typical circumstances of the accompanying crime, the typical personality traits, and their individual diversity.

I would like to draw attention to the fact that the full punishment differentiation does not exhaust the differentiation of criminal responsibility. Although it cannot be argued that these processes are not interrelated; differentiation of the latter means differentiation of punishment, which, in turn, is a component of the differentiation of this responsibility.

However, this clarification also does not fully answers to the question of elements that undergo differentiation. It is known that the Criminal Code of the Russian Federation does not contain the definition of criminal responsibility, in contrast to punishment. In theory, very different explanations are offered for the concept, content, structure, and forms of its implementation. Despite the fact that criminal responsibility is a universal and fundamental category in the criminal law, there is no certainty in the law and theory as to its essence and content. In particular, it is widely believed that criminal responsibility is the responsibility of the perpetrator to undergo the appropriate legal restrictions and deprivations arising from his/her conviction on behalf of the state [Karpushin., \& Kurlyandskiy, 1984]. The content of criminal responsibility also includes the state's duty to limit the legal status of a person, who has committed the crime, that is, to impose the burden and deprivation upon him/her [Santalov, 1982]. Some authors identify criminal responsibility with guilt [Chistyakov, 2020], with censure in the form of state condemnation of the perpetrator and the crime committed by him/her, with the actual acceptance of coercive measures by the perpetrator [Piontkovsky, 1962]. I.S. Retyunskih considers it inappropriate to divide criminal responsibility and its implementation, since there is no objective imposition of responsibility and subjective experience of the consequences of committing a crime in this case 


\section{Direite}

Periódico do Núcleo de Estudos e Pesquisas sobre Gênero e Direito

Centro de Ciências Jurídicas - Universidade Federal da Paraíba

V. 8 - No 07 - Ano 2019 - Special Edition

ISSN | 2179-7137 | http://periodicos.ufpb.br/ojs2/index.php/ged/index
[Retunskih, 1989]. According to B.V. Sidorov, the definition of criminal responsibility as a duty not to commit a crime, and when it is committed - the person's duty to be responsible to the state, supplemented by the implementation of this duty in the state-coercive measures of a criminal law nature, enables to agree with those who do not see the contradiction between its interpretation as a person's responsibility to be subjected to these coercive measures for the crime committed and to understand it as the actual application of these measures [pravo Rossii, 2013].

According to A.V. Naumov, the criminal liability should be understood as all the measures of criminal law impact, which are applied to persons, who have committed crimes. In some cases, it is exhausted by the fact of the person's conviction, that is, the decision of implying conviction without sentencing, in others - not only by condemnation, but also the application of punishment to it. [Naumov, 2016] A definition of criminal responsibility close to this understanding is given in Part 1 of Article 44 of the
Criminal Code of the Republic of Belarus, which states that it is expressed in conviction on behalf of the state upon the court's verdict for a person, who has committed the crime and the application of conviction or other criminal liability on the basis of conviction. In the Criminal Code of the Republic of Uzbekistan (Article 16), responsibility for a crime is defined as a legal consequence of a socially dangerous act, expressed in condemnation, application of punishment or other measures of criminal law influence by the court to the person guilty of the crime.

It seems to us that in the static aspect a criminal responsibility is expressed in some cases only in conviction (reprimand) of a person, who has committed a crime, expressed in the court conviction, and in others - along with this condemnation and punishment or another measure of criminal liability, in other words - another measure of a criminal law nature, and in the dynamic aspect - it (criminal liability) consists in the subjective enduring of negative consequences of committing a crime. In 
this aspect of criminal liability, it is actually about its implementation.

The definition of criminal responsibility similar to the interpretation of punishment given by the legislator in Part 1 of Article of the Criminal Code of the Russian Federation seems fruitful. Criminal liability, as a more general concept, also acts as a measure of state coercion, as defined in a court conviction. It, like punishment, is applied to a person convicted of a crime. The difference between them can be seen only in the content and targets, they depend on the implementation forms of criminal responsibility, that is, all or only some of its elements are implemented. Criminal responsibility is a universal and comprehensive criminal law measure, it covers all its more specific measures with its content - punishment, confiscation of property, conditional conviction, suspension of sentence, compulsory educational measures, compulsory medical measures, combined with the punishment execution, etc.

Taking into account the requirements of justice, the differentiation of criminal responsibility is carried out on the basis of various means (grounds) and in its various forms, in particular, on the basis of 1) the nature of public danger of crimes in sanctions for the acts with the main elements of crimes; 2) the regulation of qualified offenses and the establishment of new punishability limits, taking into account the typical properties of the degree of public danger of crime; 3 ) the regulation of sanctions for crimes with particularly qualifying features; 4) the regulation of notes to a number of articles of the Special Section of the Criminal Code of the Russian Federation, which stipulates exemption from criminal liability due to active repentance after committing a single crime (see, for example, a note to Article 126 of the Criminal Code of the Russian Federation) and bringing to justice in those situations when the perpetrator's actions contain the signs of different corpus delicti.

The main form of differentiation of criminal responsibility is carried out by the legislative regulation of sanctions, that is, the punishability limits in the norms of the Special Part of the Criminal Code of 


\section{Sireite}

Periódico do Núcleo de Estudos e Pesquisas sobre Gênero e Direito Centro de Ciências Jurídicas - Universidade Federal da Paraíba V. 8 - No 07 - Ano 2019 - Special Edition ISSN | 2179-7137 | http://periodicos.ufpb.br/ojs2/index.php/ged/index

the Russian Federation by establishing in them: 1) different types of punishments;2) the main and additional types of punishment; 3) the timing and size of punishments; 4) the differentiation of sanctions for acts with the main qualified and specially qualified compositions; 5) the regulation of compositions with a special subject of the crime.

A not smaller circle of differentiating means is stipulated in the norms of the General Part of the Criminal Code of the Russian Federation by: 1) establishing a system of types of punishment; 2) regulating the minimum and maximum limits on the timing and size of certain types of penalties; 3)regulating the ban on the appointment of certain types of punishment to certain categories of persons who have committed the crimes; 4) features of the use of penalties in the form of deprivation of the right to hold certain positions or being engaged in certain activities (Part 3 of Article 47 of the Criminal Code of the Russian Federation) and deprivation of a special, military or honorary title, class rank and state awards (Article 48 of the Criminal Code of the
Russian Federation); 5) punishability features of minors (Article 88 of the Criminal Code of the Russian Federation); 6) establishment of new punishment limits (as compared with the sanctions of Articles of the Special Part) in the presence of: a) mitigating circumstances stipulated in clauses "i", "k" of Part 1 of Article 61 of the Criminal Code of the Russian Federation (Part 1 of Article 62 of the Criminal Code of the Russian Federation); b) at the conclusion of a pre-trial agreement on cooperation (Part 2, 3, 4 of Article 62 of the Criminal Code of the Russian Federation); c) consideration of the criminal case in accordance with the procedure established by Chapter 40 of the Criminal Procedure Code of the Russian Federation (Part 5 of Article 62 of the Criminal Code of the Russian Federation); d) the purpose of punishment at the jury's verdict of condescension (Article 65 of the Criminal Code of the Russian Federation); e) sentencing for an unfinished crime (Article 66 of the Criminal Code of the Russian Federation); e) punishment appointment for the recurrence of crimes (Article 68 of the Criminal Code of the 


\section{Sireite}

Periódico do Núcleo de Estudos e Pesquisas sobre Gênero e Direito Centro de Ciências Jurídicas - Universidade Federal da Paraíba V. 8 - No 07 - Ano 2019 - Special Edition ISSN | 2179-7137 | http://periodicos.ufpb.br/ojs2/index.php/ged/index
Russian Federation); g) sentencing on cumulative crimes (Article 69 of the Criminal Code of the Russian Federation); h) sentencing on cumulative sentences (Article 70 of the Criminal Code of the Russian Federation); i) punishment appointment to a person recognized as sick with drug addiction (Article $72^{1}$ of the Criminal Code of the Russian Federation); j) application of conditional conviction (Articles 73, 74 of the Criminal Code of the Russian Federation); k) deferment of serving the sentence (Articles $82,82^{1}$ of the Criminal Code of the Russian Federation); m) replacing the unserved part of sentence with a milder one (Article 80 of the Criminal Code of the Russian Federation); m) replacement of certain types of punishment in case of threatening evasion from serving them (Articles 49, 50,53 of the Criminal Code of the Russian Federation) or in case of evasion (that is, if there is no sign of maliciousness - Article 531 of the Criminal Code of the Russian Federation or when evading fine execution (Article 47 of the Criminal Code of the Russian Federation;) o) exemption from punishment in connection with a disease
149

(Article 81 of the Criminal Code of the Russian Federation); o) exemption from serving a sentence in connection with the expiration of the statute of limitations for a court conviction (Article 83 of the Criminal Code of the Russian Federation); p) commutation according to amnesty and pardon, etc.

The above means of differentiation of criminal responsibility can be viewed through the prism of their systematic construction. Firstly, the legislator regulates the system of punishments, the terms or amounts of certain types of punishments, determines the categories of persons who cannot be given certain types of punishments, as well as the replacement of certain types of punishments with other punishments when a court makes a sentence (Articles 51, 55 of the Criminal Code of the Russian Federation) or malicious evasion from serving or executing a punishment imposed by a court. Subsequently, this differentiation is carried out through the regulation of sanctions in the norms of the Special Part of the Criminal Code, in particular, through a combination of the 
Sothinere

Periódico do Núcleo de Estudos e Pesquisas sobre Gênero e Direito

Centro de Ciências Jurídicas - Universidade Federal da Paraíba

V. 8 - No 07 - Ano 2019 - Special Edition

ISSN | 2179-7137 | http://periodicos.ufpb.br/ojs2/index.php/ged/index

main types of punishments and their combination with additional penalties, the definition of their terms (sizes). The next level of differentiation of criminal responsibility is the differentiation of the limits of punishments stipulated in connection with certain features of the commission of certain crimes, as well as the perpetrator's identity (Articles 62, 631, $65-70,72^{1}$ of the Criminal Code of the Russian Federation). And its final level in the application of punishment is carried out in the process of its execution, and it is implemented by means of mitigating or aggravating the punishment.

In addition to punishment, the differentiation of criminal responsibility is carried out by regulating other measures of a criminal law nature - conditional conviction, postponement of punishment, compulsory measures of educational influence, confiscation of property, etc. It is in this case about the criminal law impact, deprived of punitive nature. The presence of non-punitive means and, moreover, their prevalence is a feature inherent in modern criminal law.
150

The system-structural, multilevel and dualistic (punitive and nonpunitive measures) construction of the differentiation means of criminal responsibility in the Criminal Code of the Russian Federation allows ensuring the comprehensive implementation of the principle of justice, applying the most individualized and expedient punishment in each particular case of conviction for a crime.

The legislation of some modern states (Article 137 of the Criminal Procedure Code of France, $\S$ 64, 66 of the Criminal Code of Germany, etc.) stipulates preventive measures, which in fact act as a means of executing criminal responsibility and, accordingly, differentiating it. As some French authors point out, personal security measures are designed to eliminate certain criminal tendencies regarding, for example, alcoholics [Conte, 1998]. However, it seems to us that such preventive measures cannot be applied outside the commission of a crime. Although the very idea of a preventive effect on persons with criminal or semi- 


\section{Sireite}

Periódico do Núcleo de Estudos e Pesquisas sobre Gênero e Direito

Centro de Ciências Jurídicas - Universidade Federal da Paraíba

V. 8 - $\mathrm{N}^{\circ} 07$ - Ano 2019 - Special Edition

ISSN | 2179-7137 | http://periodicos.ufpb.br/ojs2/index.php/ged/index criminal "tendencies" deserves the attention of the Russian legislator.

In the Criminal Code of the Russian Federation, a definition of criminal responsibility should be given, which would allow it to be correlated with other criminal law categories - its basis, punishment, other criminal law measures, goals of this responsibility and goals of punishment, etc.

\section{Conclusions}

In our opinion, some of the innovations in the current Criminal Code of the Russian Federation do not meet the requirements of justice, in particular, giving the court the right to change the crime category to a less serious one; it can therefore, for example, change the category of a particularly serious crime to a serious crime, and meanwhile, sufficiently long terms of imprisonment and even life imprisonment are stipulated for committing these crimes or criminal acts, since they are characterized by an extremely high degree of social danger. In a general procedure, it is hardly advisable to provide for such mitigation, moreover, there are other forms of it that are individual and stimulating in nature imposing a milder punishment than those stipulated for this crime (Article 64 of the Criminal Code of the Russian Federation), conditional early release from serving the sentence (Article 79 of the Criminal Code of the Russian Federation), etc.

From the point of view of the interests of differentiation of criminal responsibility and the appointment of fair penalties, it is impossible to recognize the refusal of indications of the minimum limits of imprisonment and some other types of punishment in the sanctions of the norms of the Special Part of the Criminal Code of the Russian Federation as justified. In our opinion, the differentiation of criminal responsibility should be not less based on gradation and minimum limits of punishment. The refusal to fix the minimum limits leads to the fact that the court may determine the term of imprisonment from two months to fifteen years for committing certain crimes (for example, Part 4 of Article 111 of the Criminal Code of the Russian Federation). As we see it, the law should establish the 
Sateinere

Periódico do Núcleo de Estudos e Pesquisas sobre Gênero e Direito Centro de Ciências Jurídicas - Universidade Federal da Paraíba V. 8 - No 07 - Ano 2019 - Special Edition ISSN | 2179-7137 | http://periodicos.ufpb.br/ojs2/index.php/ged/index

152

contours of justice punishment. Moreover, such an approach cannot exclude the abuse of excessively broad judicial discretion.

In our opinion, the exclusion of property confiscation from the system of punishment types in 2003 also does not meet the requirements of justice. Although three years later it was again settled in the Criminal Code of the Russian Federation, however, it was in some capacity - as a different measure of criminal law. As a result, its application was limited to a number of conditions and reservations, which reduced its appointment to individual cases. And all these "innovations" were undertaken by the legislator in an atmosphere of unacceptably high levels of corruption, abuse and theft. Therefore, it would be fair to stipulated the confiscation of all the property, the acquisition of which cannot be explained by a person, who has committed a crime.

As a result, we note that the differentiation of criminal responsibility is key in establishing and implementing fair measures of criminal law response to the facts of committing crimes. A fair

differentiation of responsibility predetermines the social effect of criminal law in general. It does not exclude the use of punishments with a high punitive potential, including the death penalty for particularly cruel facts of numerous murders, confiscation of property not only of those guilty of a crime, but also of their family members, who have been living together for five years before their conviction. From these positions, it also seems reasonable and fair to increase the minimum sentence of imprisonment for committing grave and especially grave crimes.

\section{References}

Albrecht H.J. (2015). Sentencing in Germany: Explaining Long-Term Stability in the Structure of Criminal Sanctions and Sentencing. - Law and Contemporary Problems, 76 (1), P. 211236.

Berar C. (2014). The individualization of punishment according to the new criminal code. $\quad$ - URL: 
SatGinere

Periódico do Núcleo de Estudos e Pesquisas sobre Gênero e Direito Centro de Ciências Jurídicas - Universidade Federal da Paraíba V. 8 - $\mathrm{N}^{\circ} 07$ - Ano 2019 - Special Edition ISSN | 2179-7137 | http://periodicos.ufpb.br/ojs2/index.php/ged/index

http://www.ipe.ro/RePEc/WorkingPapers/

wpconf151203.pdf.

Chistyakov A.A. (2020). Criminal Liability and the Mechanism of its Foundation. - M.: Zakon i Pravo, 2002. P. 43.

Conte P., (1998). Maistre du Chambon p.

Droit penal general. P., 1998. P. 237.

Cornel O. (2010). Differentiation and individualization of the penalty of imprisonment, (deprivation of liberty). URL: http://

www.cnaa.md/en/thesis/16124.

Karpushin, M. P., \& Kurlyandskiy, V. I. (1984). Criminal responsibility and corpus delicti. M, 984, 39.

Naumov A.V. (2016). Russian Criminal

Law: Lecture Course: in 3 volumes. V. 1: Common Part. - M.: Federal Chamber of Lawyers of the Russian Federation, 2016. P. 426.
153

Piontkovsky A.A. (1962). The Doctrine of the Crime. - M., 1962. P. 45.

pravo Rossii, U. (2013). Obshchaya chast'[Criminal law of Russia. A common part]. Tyumen, Tyumen Advanced Training Institute of the Ministry of the Interior of the Russian Federation.

Retunskih I.S. C(1989). riminal Responsibility and its Implementation under the Soviet Legislation // Criminal Responsibility: Problems of Maintenance, Establishment, Implementation. - Voronezh: Publishing House of the Voronezh University, 1989. P. 113.

Santalov A.I. (1982). The Theoretical Basis of Criminal Liability. - L.: Publishing House Leningradsk. University, 1982. P. 12. 